Канівець Н. С., кандидат ветеринарних наук

Полтавська державна аграрна академія

\title{
НЕФРОЛІТІАЗ У КОРІВ: ДІАГНОСТИКА ЗАБІЙНИХ ТВАРИН
}

\author{
Рецензент - доктор ветеринарних наук В. О. Свстаф'єва
}

Мета статmі - висвітлити дані стосовно захворювання великої рогатої худоби на нефролітіаз у Полтавській області з урахуванням уже наявних літературних даних щзодо поширення вказаної патологї.

Методика дослідження. У процесі виконання роботи проводили ветеринарно-санітарну експертизу внутрішніх органів (нирок) великої рогатої худоби при забої, виявляли органолептично нефроліти та визначали їх параметри.

Результати дослідження. У роботі наведено результати досліджень щодо ураження нирок корів нефролітами. Нефролітіаз був встановлений у n'яти (2,1\%) із 243 голів. Виявлено локалізацію ниркових каменів, величину, масу та колір.

Елементи наукової новизни. Невеликі камені (пісок) у корів виявлені в ниркових чашечках.

Практична значущість. 3'ясування ролі екологічних та аліментарних факторів у розвитку ниркових каменів у корів заслуговують на увагу.

Ключові слова: нирки, нефролітіаз, корова, ниркові камені, нефроліти.

Наталія Сергї̈вна Канівець - кандидат ветеринарних наук, доцент кафедри терапії ім. проф. П. І. Локеса, Полтавська державна аграрна академія, вул. Сковороди, 1/3, м. Полтава, 36003, Україна, e-mail: nataliia.kanivets@pdaa.edu.ua, ORCID ID: 0000-0001-9520-2999.

Постановка проблеми у загальному вигляді. Нефролітіаз - захворювання, що характеризується утворенням і локалізацією каменів у нирці [4]. Ця патологія як різновид сечокам'яної хвороби реєструється у тварин різних видів та людини [2, 11]. Зокрема, у великої рогатої худоби за надмірного споживання білкових кормів у сечі відбувається формування органічного осаду, що накопичується в ниркових канальцях та чашечках. Утворені уроліти, по-перше знижують продуктивність тварин, по-друге - призводять до передчасного їх вибракування та забою, що призводить до значних економічних збитків [11].

Аналіз останніх досліджень і публікацій, у яких започатковано розв'язання проблеми. Дослідження патогенезу сечокам'яної хвороби свідчить про те, що утворення каменів у сечі $\epsilon$ результатом досить складних фізико-хімічних процесів. Поєднання певного типу умов призводить до перетворення групи молекул у міцели, що $є$ основою для подальшого формування конкременту [3]. Нитки фібрину, чужорідні тіла у складі сечі, клітинний детрит, аморфні осади $є$ матеріалом, що нашаровується на ядро уроліта. Процес каменеутворення, безпосередньо, визначається ступенем співвідношення і концентрації в сечі солей, реакцією рН (концентрація іонів водню), кількісним і якісним складом сечових колоїдів, і вражає ниркові сосочки [7]. Спочатку в збірних канальцях відбувається утворення мікролітів, більша частина яких не затримується в нирках (фізіологічно вимивається сечею). Однак за зміни хімічних властивостей сечі відбувається активація процесів кристалізації. Мікроліти в канальцях затримуються внаслідок їх інкрустації в сосочки. Надалі нефроліт або розростається в нирці, або переміщується до сечовивідних шляхів [5].

У деяких випадках за нефролітіазу клінічні ознаки захворювання відсутні, в інших - може виникати обструкція ниркової миски, чи сечоводу, що провокує розвиток пієлонефриту і ниркової недостатності [8]. Водночас, камені, які не блокують сечовивідні шляхи, призводить до інфекційних запалень тканин та їх дегенеративних змін [4].

За даними літератури, в деяких районах Північної Америки, Австралії, США та Індії відмічається значна загибель жуйних тварин внаслідок закупорення уретри великими каменями, що $\epsilon$ серйозною проблемою [14]. Обструкція частіше реєструється у кастрованих самців, ніж у інтактних самців або самиць (відмінності в анатомії уретри) [12]. Дослідники встановили, що розміри уролітів досить різні, починаючи від декількох міліметрів (пісок у нирках), до десятку сантиметрів [10]. Форма також може відрізнятися, традиційними варіантами є пласкі камені, 


\section{ВЕТЕРИНАРНА МЕДИЦИНА}

коралоподібні, або округлі $[7,13]$.

Вивчення поширеності нефролітіазу, локалізація та структура нефролітів має важливе значення у профілактиці і лікуванні ускладнень сечовидільної системи, що, безумовно, $\epsilon$ актуальним.

У зв'язку із цим метою роботи було дослідження нирок забійних корів та виявлення в них каменів (нефролітіаз).

У завдання досліджень входило встановити кількість голів корів 3 нефролітіазом, визначити локалізацію нефролітів, їх розмір, структуру, масу та вид.

Матеріали і методи досліджень. Дослідження нирок великої рогатої худоби проводилися в умовах забійного цеху м. Полтава в осінній період 2018 року. Відбір зразків органу проводили від 243 голів корів української чорнорябої породи віком від 3 до 5 років.
Під час ветеринарно-санітарної експертизи внутрішніх органів виявляли уражені каменями нирки. Для цього їх оглядали зовні та на розрізі (поперечному і повздовжньому). Візуально визначали локалізацію та колір ниркових каменів; величину за допомогою лінійки (ГОСТ 1743572); масу - зважуванням на електронних вагах AXIS A500R.

Результати досліджень. Результати проведеної ветеринарно-санітарної експертизи виявили у п'яти тварин наявність каменів у нирках, що становило близько 2,1 \% від загальної кількості забитих тварин.

Нефроліти локалізувалися, переважно, в сечоводах, дещо рідше - в нирковій чашці (рис. 1).

Ниркові камені мали різні розміри від 1 до 14 мм, подекуди відмічали дуже маленькі камені у вигляді піщинок, так званий нирковий пісок (рис. 2).

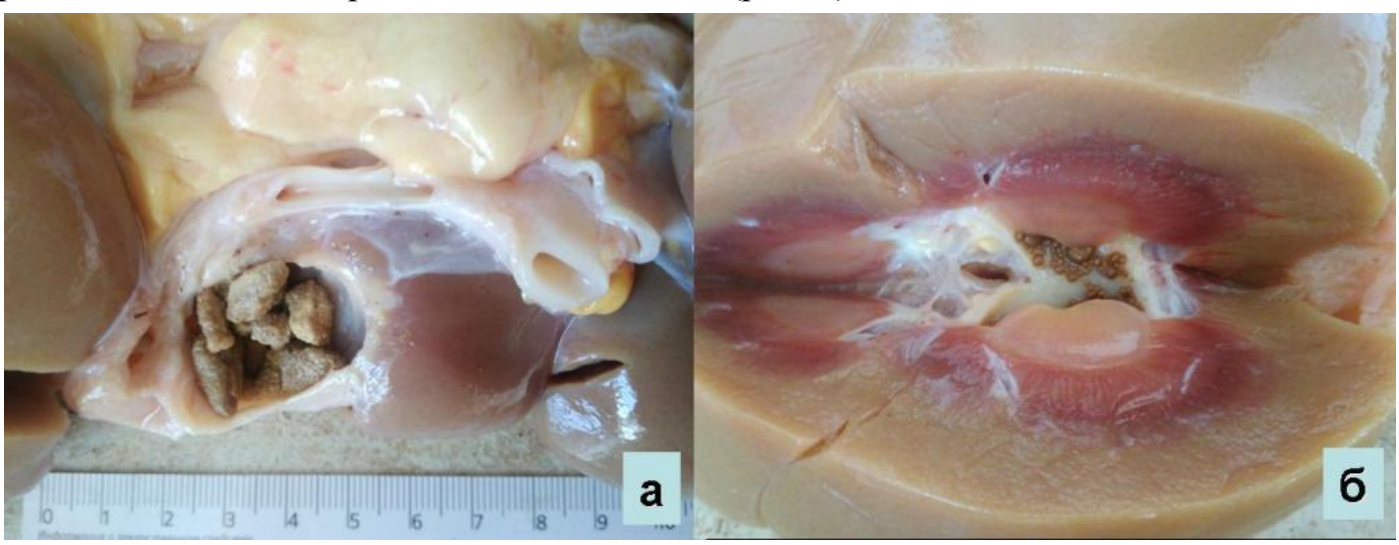

Рис. 1. Локалізація каменів у нирках корів: сечовод (а), ниркова чащечка (б)

Джерело: власні результати.

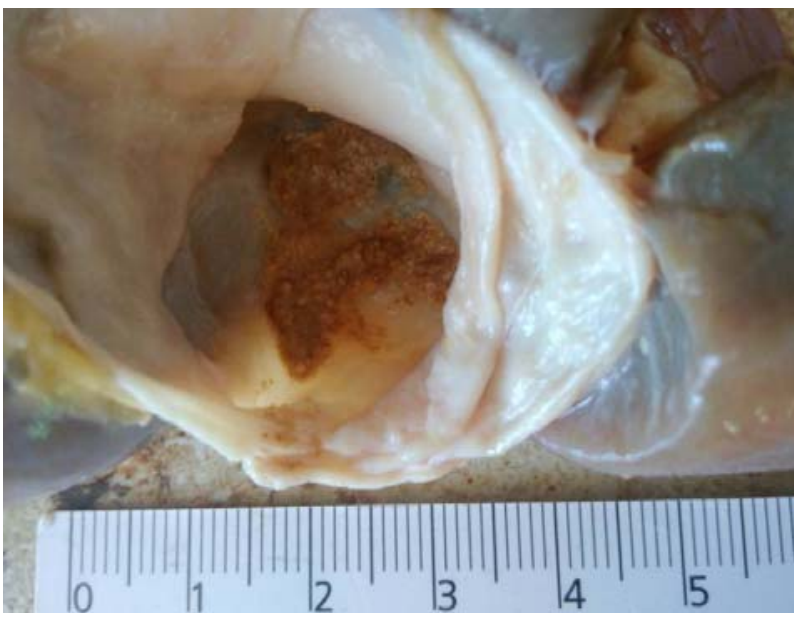

Рис. 2. Нирковий пісок в сечоводі великої рогатої худоби

Джерело: власні результати. 


\section{ВЕТЕРИНАРНА МЕДИЦИНА}

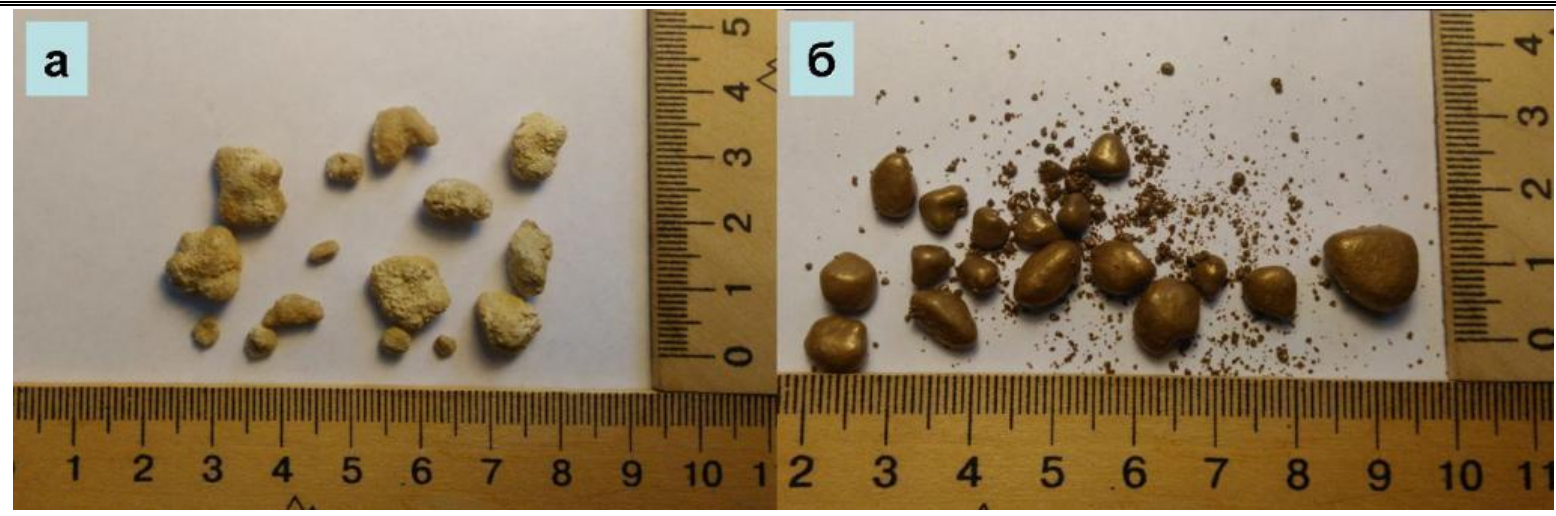

Рис. 3. Численні сірі камені неправильної форми, з шипуватою поверхнею і твердою консистенцією (а); численні м'які жовто-сірі камені, округлоӥ форми, з гладкою поверхнею (б) локалізовані в нирковій чашці

Джерело: власні результати.

Водночас, нефроліти різнилися за формою. Окремі камені були великими і твердими, інші маленькими піщаноподібними (рис. 3). Зовні вони мали гладеньку, або шершаву (шипувату) поверхню. Колір варіював від світло-сірого до жовтосірого. Маса нефролітів була від 2,1 мг (найдрібніші камені) до 0,98 г (найбільші). Нерідко у процесі дослідження нирок відмічали поодинокі кісти різного розміру. Характер і будова кістозних утворень нирок наводились у попередній публікації [1].

Аналіз конкрементів показав їх змішаний склад (оксалат кальцію, фосфат магнію, фосфат кальцію та урат амонію), що має подібність з результатами інших дослідників $[10,11]$ та узгоджується з гіпотезою про різноманітність складу уролітів великої рогатої худоби.

Оксалатний склад уролітів, обумовлений випасанням корів на пасовищах із високим вмістом оксалатів у грунті $[7,12,15]$. Розчинні оксалати всмоктуються в рубці жуйних, з'єднується із кальцієм сироватки крові, утворюючи нерозчинні кристали

\section{БІБЛІОГРАФІЯ}

1. Канівець Н. С. Морфологічні дослідження нирок великої рогатої худоби за кістозних утворень. Проблеми зооінженерії та ветеринарної медицини : Зб. наук. праць Харків. держ. зоовет. академії. Харків : РВВ ХДЗВА., 2018. Вип. 35. ч. 2. т. 3 «Ветеринарні науки». С. 162-164.

2. Особенности иммунологических расстройств при остром серозном пиелонефрите в зависимости от типа рецидивного течения кальциевого нефролитиаза / Ельський В. Н. и др. Клінічна та експериментальна патологія. 2009. Том VIII, № 3 (29). C. 23-27.

3. Aggarwal K. P., Narula S., Kakkar M., Tan- кальцію оксалату, які у процесі фільтрації осідають у нирках [6]. Клінічно може розвиватися хронічна ниркова недостатність, гіпокальціємія, вторинний гіперпаратиреоз та отруєння оксалатом кальцію [9].

Аналізуючи результати наших досліджень та дані інших науковців щодо нефролітіазу у корів [10, 11] можна зробити висновок, що ця патологія у великої рогатої худоби не має виражених клінічних ознак, встановлення діагнозу зазвичай $\epsilon$ випадковим під час ветеринарно-санітарної експертизи нирок.

Висновки 3 даного дослідження і перспективи подалыших розвідок у даному напрямі. Діагноз на нефролітіаз у корів встановлюється при забої тварин. Камені локалізуються в ниркових чашках та сечоводах, мають різну форму, колір, масу та будову.

На нашу думку, подальші дослідження щодо з'ясування ролі екологічних та аліментарних факторів у розвитку ниркових каменів у корів заслуговують на увагу.

don C. Nephrolithiasis: Molecular Mechanism of Renal Stone Formation and the Critical Role Played by Modulators. BioMed Research International. 2013. DOI: 10.1155/2013/292953.

4. Bilbault H., Haymann J. P. Experimental models of renal calcium stones in rodents. World $J$ Nephrol. 2016. Vol. 5 (2). P. 189-194.

5. Hoppe B., Beck B. B., Milliner D. S. The primary hyperoxaluria. Kidney Int. 2009. Vol.75 (12). P. 1264 1271. DOI: 10.1038/ki.2009.32.

6. Lincoln S. D., Black B. Halogeton poisoning in range cattle. J Am Vet Med Assoc. 1980. Vol. 176. P. 717-718. 


\section{ВЕТЕРИНАРНА МЕДИЦИНА}

7. Macbeth B. J. Obstructive urolithiasis, unilateral hydronephrosis, and probable nephrolithiasis in a 12year-old Clydesdale gelding. Can Vet J. 2008. Vol. 49. P. 287-290.

8. Makhdoomi D. M. \& Gazi, M. A. Obstructive urolithiasis in ruminants - A review. Vetworld. 2013. P. 233-238.

9. Marais J. P. Nitrate and Oxalates. Handbook of plant and fungal toxicants. CRC Press Boca Raton, New York, 1997.

10. Onmaz A.C., Albasan H., Lulich J.P., Osborne C. A., Gunes $V$. et al. Mineral composition of uroliths in cattle in the region of Kayseri. J Fac Vet Med Univ Erciyes. 2012. Vol. 9. P. 175-181.

11. Oryan A., Azizi S., Kheirandish R., Hajimirzae M. R. Nephrolithiasis among Slaughtered Cow in Iran: Pathology Findings and Mineral Compositions. $J$

\section{REFERENCES}

1. Kanivets, N. S. (2018). Morfolohichni doslidzhennya nyrok velykoyi rohatoyi khudoby za kistoznykh utvoren [Morphological study of cattle kidneys at cystic formations]. Problemy zooinzheneriyiyi ta veterynarnoyi medytsyny. Kharkiv. derzh. zoovet. akademiyi, 35. (2:3), pp. 162-164 [In Ukrainian].

2. Yelskiy, V. N., Guzenko, V. N., Krivobok, A. G. \& Zolotukhin, S. Ye. (2009). Osobennosti immunologicheskikh rasstroystv pri ostrom seroznom piyelonefrite $\mathrm{v}$ zavisimosti ot tipa retsidivnogo techeniya kal'tsiyevogo nefrolitiaza [Features of immunological disorders in acute serous pyelonephritis, depending on the type of recurrent calcium nephrolithiasis]. Klínichna ta yeksperimentalna patologíya, 8 (3:29), pp. 23-27 [In Russian].

3. Aggarwal, K. P., Narula, S., Kakkar, M., Tandon, C. (2013). Nephrolithiasis: Molecular Mechanism of Renal Stone Formation and the Critical Role Played by Modulators. BioMed Research International, DOI: 10.1155/2013/292953 [In English].

4. Bilbault, H., Haymann, J. P. (2016). Experimental models of renal calcium stones in rodents. World J Nephrol, 5(2). pp. 189-194 [In English].

5. Hoppe, B., Beck, B. B., Milliner, D. S. (2009). The primary hyperoxaluria. Kidney Int., 75 (12), pp. 1264-1271. DOI: 10.1038/ki.2009.32 [In English].

6. Lincoln, S. D., Black, B. (1980) Halogeton poisoning in range cattle. $J \mathrm{Am}$ Vet Med Assoc., 176, pp. 717-718 [In English].

7. Macbeth, B. J. (2008) Obstructive urolithiasis, unilateral hydronephrosis, and probable nephrolithiasis in a 12-year-old Clydesdale gelding. Can Vet J., 49, pp. 287-290 [In English].
Vet Sci Med Diagn. 2015. Vol 4:1. DOI: http://dx.doi.org/2325-9590.1000148.

12. Osborne C.A., Albasan H., Lulich J.P., Nwaokorie E., Koehler L. A. et al. Quantitative analysis of 4468 uroliths retrieved from farm animals, exotic species, and wildlifes to the Minnesota Urolith Center: 1981 to 2007. Vet Clin North Am Small Anim Pract. 2009. Vol. 39. P. 65-78.

13. Robinson M.R., Norris R.D., Sur R.L., Preminger G. $M$. Urolithiasis: not just a 2-legged animal disease. J Urol. 2008. Vol. 179, P. 46-52.

14. Silica metabolism and silica urolithiasis in ruminants: a review Article in The Canadian veterinary journal La revue veterinaire canadienne. 1981. Vol. 61 (2). P. 219-235. doi:10.4141/cjas81-031.

15. Smith, B. P. Large Animal Internal Medicine. 4th edtn Mosby Inc Elsevier St. Louis, 2009.

8. Makhdoomi, D. M. \& Gazi, M. A. (2013). Obstructive urolithiasis in ruminants - A review. Vetworld, pp. 233-238 [In English].

9. Marais, J. P. (1997). Nitrate and Oxalates. Handbook of plant and fungal toxicants. CRC Press Boca Raton, New York [In English].

10. Onmaz, A. C., Albasan, H., Lulich, J. P., Osborne, C. A., Gunes, V., et al. (2012). Mineral composition of uroliths in cattle in the region of Kayseri. $J$ Fac Vet Med Univ Erciyes, 9, pp. 175-181 [In English].

11. Oryan, A., Azizi, S., Kheirandish, R., Hajimirzae, M. R. (2015). Nephrolithiasis among Slaughtered Cow in Iran: Pathology Findings and Mineral Compositions. $J$ Vet Sci Med Diagn, 4:1. DOI: http://dx.doi.org/2325-9590.1000148 [In English].

12. Osborne, C. A., Albasan, H., Lulich, J.P., Nwaokorie, E., Koehler, L. A., et al. (2009). Quantitative analysis of 4468 uroliths retrieved from farm animals, exotic species, and wildlifes to the Minnesota Urolith Center: 1981 to 2007. Vet Clin North Am Small Anim Pract, 39, pp. 65-78 [In English].

13. Robinson, M. R., Norris, R. D., Sur, R. L., Preminger, G. M. (2008). Urolithiasis: not just a 2legged animal disease. $J$ Urol, 179, pp. 46-52 [In English].

14. Silica metabolism and silica urolithiasis in ruminants: a review Article in The Canadian veterinary journal (1981). La revue veterinaire canadienne, 61 (2), pp. 219-235. DOI:10.4141/cjas81031 [In English].

15. Smith, B. P. (2009). Large Animal Internal Medicine. 4th edtn Mosby Inc Elsevier St. Louis [In English]. 


\section{ВЕТЕРИНАРНА МЕДИЦИНА}

Канивец Н. С. Нефролитиаз у коров: диагностика убойных жсивотных

Цель статьи - показать данные о заболевании крупного рогатого скота на нефролитиаз в Полтавской области с учетом известных уже литературных данных по распространению указанной патологии.

Методика исследования. В прочессе выполнения работы проводили ветеринарно-санитарную экспертизу внутренних органов (почек) крупного рогатого скота при убое, проявляли органолептически нефролиты и определяли их параметры.

Результаты исследования. В работе приведены результаты исследований по поражению почек коров нефролитами. Нефролитиаз был установлен у пяти (2,1\%) из 243 голов. Выявлено локализациню почечных камней, размер, массу и извет.

Элементы научной новизны. Небольшие камни (песок) у коров обнаружены в почечных чашечках.

Практическая значимость. Выяснение роли экологических и алиментарных факторов в развитии почечных камней у коров заслужсвают внимания..

Ключевые слова: почка, нефролитиаз, корова, почечные камни, нефролитьл.

Канивец Наталия Сергеевна - кандидат ветеринарных наук, доцент кафедры терапии имени профессора П. И. Локеса, Полтавская государственная аграрная академия, ул. Сковороды, 1/3, г. Полтава, 36003, Украина, e-mail: nataliia.kanivets@pdaa.edu.ua, ORCID ID: 0000-0001-9520-2999.

\section{Kanivets N. S. Nephrolithiasis of cows: diagnostics of slaughter animals}

The purpose of the article is to highlight data on bovine nephrolithiasis disease in Poltava region, taking into account the available information on spreading of this pathology.

Research methods. In the process of work we conducted veterinary-sanitary expert examination of the internal organs (kidneys) of cattle at slaughtering, organoleptically detected nephroliths and determined their parameters.

Research results. The results of the conducted veterinary-sanitary expert examination revealed stones in the kidneys in five animals, which was about $2.1 \%$ of the total number of slaughtered animals.

Uroliths were localized, mainly in the ureter, and less frequently in the calix renalis.

Kidney stones were of different sizes from 1 to $14 \mathrm{~mm}$, in some cases, very small stones in the form of sand grains, the so-called renal sand.

At the same time, uroliths differed in shape. The some stones were large and solid, others were small and sandy. Externally, they had a smooth or rough (thorny) surface. The color varied from light gray to yellowgray. The weight of uroliths varied from $2.1 \mathrm{mg}$ (the smallest stones) to $0.98 \mathrm{~g}$ (the largest stones). Not rarely, during examining the kidneys, isolated cysts of different sizes were detected, which were filled with light-serous fluid.

The analysis of calculus showed its mixed composition (calcium oxalate, magnesium phosphate, calcium phosphate and ammonium urate), which is similar to the results of other researchers and it is coordinated with the hypothesis of the diversity of uroliths' composition in cattle.

The elements of scientific novelty. Small stones (sand) are found in the calix renalis of cows.

Practical significance. Clarifying the role of ecological and alimentary factors in the development of kidney stones in cows deserves attention.

Key words: kidneys, nephrolithiasis, cow, kidney stones, nephroliths.

Kanivets Nataliia Serhiivna - Candidate $(\mathrm{PhD})$ of Veterinary Sciences, Associate Professor of the Department of Therapy named after Professor P. I. Lokes, Faculty of Veterinary Medicine, Poltava State Agrarian Academy, 1/3, Skovorody st., Poltava, 36003, Ukraine, e-mail: nataliia.kanivets@pdaa.edu.ua, ORCID ID: 0000-0001-9520-2999.

Бібліографічний опис для цитування :

Стаття надійшла до редакції 15.02.2019 р.

Канівецьь Н. С. Нефролітіаз у корів: діагностика забійних тварин. Вісник ПДАА. 2019. № 1. C. $181-186$.

DOI 10.31210/visnyk2019.01.20

(C) Канівець Наталія Сергї̈вна, 2019

№ 1 • 2019 • ВІСНИК Полтавської державної аграрної академії 